\title{
Nitrogen-Fixing Bacterial Communities Exhibit Strong Spatial Structure along a Slope Gradient in Karst Shrublands Ecosystem
}

\author{
Yueming Liang ${ }^{2}$, Xunyang $\mathrm{He}^{1,3}$, Xiangbi Chen ${ }^{1,3}$, Yajun $\mathrm{Hu}^{1,3}$, Yirong $\mathrm{Su}^{1,3 *}$ \\ ${ }^{1}$ Key Laboratory of Agro-ecological Processes in Subtropical Region, Institute of Subtropical Agriculture, \\ Chinese Academy of Sciences, Changsha, China \\ ${ }^{2}$ Institute of Karst Geology, CAGS, Karst Dynamics Laboratory, MLR, Guilin, China \\ ${ }^{3}$ Key Laboratory of Karst Dynamics, Ministry of Nature and Resources \& Guangxi Zhuang Autonomous, \\ Institute of Karst Geology, Chinese Academy of Geological Science, Karst Dynamics Laboratory, \\ Ministry of Nature and Resources, Guilin, 541004, China
}

Received: 28 April 2018

Accepted: 16 August 2018

\begin{abstract}
Environmental heterogeneity is a primary factor in determining soil microbial spatial patterns. However, few studies have demonstrated a link between environmental heterogeneity and the spatial patterns in free-living nitrogen-fixing bacteria, which are important in nitrogen cycling. Here, quantitative polymerase chain reaction and terminal restriction fragment length polymorphism were used to determine the spatial distribution of free-living nitrogen-fixing bacteria along a slope gradient. Plant communities were evaluated through field surveys, and basic soil properties were measured in the laboratory. Soil properties (e.g., soil available phosphorus, soil organic carbon, and total nitrogen) were higher in upper- and middle -slope soils than in lower-slope soils, while bacterial abundance was the opposite. Bacterial and plant communities all varied along the slope gradient. Redundancy analysis revealed that bacterial community composition was closely linked to $\mathrm{pH}$, soil organic carbon, available phosphorus, and total nitrogen. These results indicate that free-living nitrogen-fixing bacterial communities show strong spatial structure along a slope gradient, and emphasize the importance of soil heterogeneity in affecting bacterial spatial patterns in a karst region.
\end{abstract}

Keywords: free-living nitrogen-fixing bacteria, environmental heterogeneity, karst shrubland, community spatial distribution

*e-mail: yrsu@isa.ac.cn 


\section{Introduction}

Understanding the spatial distribution patterns of organisms is a fundamental aim of ecology, because it is conducive to predicting how organisms respond to the environment. Spatial scaling has a long history in plant and animal ecology but has only recently been addressed at the microbial level [1]. However, interest in investigating microbial niches is now increasing [2-4], as the importance of functional microbes (e.g., nitrogen-fixing bacteria and arbuscular mycorrhizal fungi) in ecosystem processes become widely appreciated.

Nitrogen-fixing bacteria are critical to nitrogen cycling in terrestrial ecosystems. They are highly diverse and generally organized into two groups: symbiotic nitrogen-fixing bacteria (Rhizobia, Frankia, Cyanobacteria) [5] and free-living nitrogen-fixing bacteria (e.g., Pseudomonas, Azospirillum, and Azotobacter). Legume nitrogen fixation by symbiotic rhizobia typically accounts for $~ 80 \%$ of total biological nitrogen fixation [6], but in some soils, free-living nitrogen-fixing bacteria can fix significant amounts of nitrogen [7] and can even be the main source of fixed nitrogen [8]. Therefore, these bacteria may be particularly important in nitrogen-limited ecosystems that lack legumes, as plants in such areas would be dependent on free-living bacteria for access to fixed nitrogen.

Karst shrubland ecosystem, where few legumes exist [9], and vegetation is more limited by low nitrogen availability than in several major ecosystems, such as tussock grasslands and primary forests [10]. Moreover, soil nutrients and plant communities in shrub ecosystem exhibit higher spatial heterogeneity compared with other ecosystems in karst regions [11], making shrub ecosystem of karst regions ideal for investigating the effect of environmental heterogeneity on microbes. Previous research has demonstrated that slope position is the main factor leading to higher spatial heterogeneity of soil nutrients and plant communities in a karst shrub ecosystem [11, 12]. Additionally, studies have shown that variation in both of these abiotic and biotic factors (edaphic properties; plant species) [13, 14] influences free-living nitrogen-fixing bacterial communities. Therefore, an improved understanding of what determines spatial patterns in bacterial distribution along a slope gradient will advance efforts to understand potential fixation nitrogen for this bacteria in shrub ecosystem of karst regions. The major objectives of this study were to: 1) investigate the spatial patterns of free-living nitrogen-fixing bacterial communities along a slope gradient and 2) explore how plant communities and soil properties affect these bacterial communities in a karst shrub ecosystem. We hypothesized that variation in plant communities and soil properties between upper and lower slopes would result in strong spatial structure among free-living nitrogen fixers.

\section{Materials and Methods}

\author{
Study Area
}

The study site was located in Huanjiang County, in the Guangxi autonomous region of southwestern China $\left(107^{\circ} 51^{\prime}\right.$ to $108^{\circ} 43^{\prime} \mathrm{E}, 24^{\circ} 44^{\prime}$ to $\left.25^{\circ} 33^{\prime} \mathrm{N}\right)$. This region is dominated by a subtropical mountainous monsoon climate, with a mean annual rainfall of $1,389 \mathrm{~mm}$ and a mean annual air temperature of $18.5^{\circ} \mathrm{C}$. The wet season, during which $70 \%$ of the annual precipitation occurs, lasts from April to August [15].

Soil Sampling and Plant Survey

In June 2012, three transects were chosen along a slope gradient (altitude, 275-600 m) in Tongjin village. Three sampling plots were designated at each transect, and plots were approximately $100 \mathrm{~m}$ apart. Environmental factors, including lithology (dolomite) and slope aspect (northwest), were considered for establishing plots. From each plot, 15 soil cores (diameter, $5 \mathrm{~cm}$ ) were collected and mixed to form one composite soil sample. This method ensured that samples were representative of each site. Nine soil samples (depth, $0-15 \mathrm{~cm}$ ) were collected along the slope gradient (i.e., three transects $\times$ three slope position $=9$ soil samples). Each soil sample was divided into two subsamples. One subsample (approximately $50 \mathrm{~g}$ ) was immediately frozen in liquid nitrogen and transported to the laboratory for molecular analysis. The other subsample was air-dried for analysis of soil physicochemical properties.

Plots for plant surveys were $10 \times 10 \mathrm{~m}^{2}$. Each plot was divided into two layers: shrubby (stem diameter $<2.5 \mathrm{~m}$ ) and herbaceous (climbing plants, ferns). All plant species in both layers were identified and the following characteristics were measured: fascicle count, plant height, cover, and density.

\section{DNA Extraction from Soil}

Microbial DNA was extracted, in triplicate, from $500 \mathrm{mg}$ of freeze-dried soil using the sodium dodecyl sulfate-guanidine isothiocyanate-polyethylene glycol (SDS-GITC-PEG) method, as described by Chen et al. [16]. The extracted DNA was dissolved in $50 \mu \mathrm{L}$ sterilized water. We determined DNA concentration using a spectrophotometer (NanoDrop; PeqLab, Germany) and then stored the samples at $-20^{\circ} \mathrm{C}$ until needed for further analysis.

\section{Polymerase Chain Reaction (PCR) Amplification and Terminal Restriction Fragment Length Polymorphism (T-RFLP) Analyses}

The composition of the free-living nitrogen-fixing bacterial community was estimated with T-RFLP. Primer pairs PolF/PolR were used [9], and the forward primer was labeled at the 5' end with 6-carboxy-fluorescein (FAM; Invitrogen, China). The reaction volume was 
$50 \mu \mathrm{L}: 25 \mu \mathrm{L} 2 \times$ PCR Premix (0.1 U Prime STAR HS DNA polymerase, $0.5 \mathrm{mM}$ deoxyribonucleoside triphosphate (dNTPs)), $10 \mathrm{pM}$ of each primer, $20 \mathrm{ng}$ genomic DNA, and $19 \mu \mathrm{L} \mathrm{H}_{2} \mathrm{O}$. The cycling parameters were as follows: $2 \mathrm{~min}$ at $95^{\circ} \mathrm{C}$; followed by 35 cycles of $30 \mathrm{~s}$ at $95^{\circ} \mathrm{C}, 60 \mathrm{~s}$ at $55^{\circ} \mathrm{C}$, and $60 \mathrm{~s}$ at $72^{\circ} \mathrm{C}$; and a final 10 -min extension at $72^{\circ} \mathrm{C}$. The labeled PCR products were purified using the QIAquick PCR purification kit (Tiangen Biotech Ltd., China) and quantified using NanoDrop ND-1000 (Thermo Scientific, USA). The fluorescent-labeled products (approximately $200 \mathrm{ng}$ ) for the bacterial nifH gene were digested with HaeIII enzymes, and then analyzed using an automated sequencer (model 373A; Applied Biosystems, Weiterstadt, Germany) by Sunny Company (Shanghai, China).

Sample T-RFLP profiles were processed using the Gene Scan analysis software package (version 2.1; Applied Biosystems). Peak areas of terminal restriction fragments (T-RFs) that differed by \pm 2 bp were summed and considered as one fragment. The relative abundance (RA) of each T-RF was calculated from $\mathrm{RA}=(n i / N) \times 100$, where $n i$ represents the peak area of one distinct T-RF, and $\mathrm{N}$ is the sum of all peak areas in one sample. Minor peaks, where the relative abundance was $<1 \%$, were considered background noise [17] and excluded from statistical analyses. Dominant fragments were defined as T-RFs greater than $10 \%$ of the total peak height [18].

\section{Quantitative Analysis of nifH Genes}

We performed quantitative PCR (qPCR; ABI 7900, Foster City, CA) of the nifH gene, again using PolF/PolR primers. The reaction volume was $10 \mu \mathrm{L}$, containing
$5 \mu \mathrm{L} 1 \times$ synergy brands (SYBR) Premix, $0.2 \mu \mathrm{M}$ of each primer (Invitrogen, China), ExTaq, 0.2 $\mu \mathrm{L}$ Rox (Takara Bio, Shiga, Japan), $1 \mu \mathrm{L}$ DNA template (diluted to $5 \mathrm{ng}$ DNA $\mu \mathrm{L}^{-1}$ using sterile water), and $3.4 \mu \mathrm{L}$ sterilized water. The thermal protocol was $20 \mathrm{~s}$ at $95^{\circ} \mathrm{C}$; five cycles each of $15 \mathrm{~s}$ at $95^{\circ} \mathrm{C}, 20 \mathrm{~s}$ at $64^{\circ} \mathrm{C}$, and $15 \mathrm{~s}$ at $72^{\circ} \mathrm{C} ; 35$ cycles each of $15 \mathrm{~s}$ at $95^{\circ} \mathrm{C}, 25 \mathrm{~s}$ at $60^{\circ} \mathrm{C}$, and $15 \mathrm{~s}$ at $72^{\circ} \mathrm{C}$.

A standard curve ranging from $10^{2}$ to $10^{8} \mu \mathrm{l}^{-1}$ bacterial copies was generated using 10 -fold serial dilutions of a plasmid $\left(10^{10}\right.$ copies $\left.\mu \mathrm{l}^{-1}\right)$. The plasmid contained a partial fragment of the bacterial nifH gene from Bradyrhizobium sp. ISA1601 (KF859886). The reactions for standard curve samples, negative controls without template DNA, and soil DNA samples were performed in a single 384-well plate. Four technical replicates were used for each sample. Data analysis was performed automatically using the SDS 2.3 software included with the real-time PCR system. The efficiency of the reaction was $98 \%$ for the nifH gene. The $R^{2}$ value for the standard curve was above 0.99 and one sharp peak was observed for the standard curve.

\section{Soil Physicochemical Properties}

Soil $\mathrm{pH}$ was determined with a soil:water ratio of 1:2.5 (w/v), using a $\mathrm{pH}$ meter (Delta 320; MettlerToledo Instruments Ltd., China). Soil organic carbon was measured using $\mathrm{K}_{2} \mathrm{Cr}_{2} \mathrm{O}_{7}-\mathrm{H}_{2} \mathrm{SO}_{4}$ oxidation-reduction titration, and total nitrogen was determined with the Kjeldahl method [19]. Available phosphorus was extracted with $0.5 \mathrm{M}$ sodium bicarbonate and analyzed using the Mo-Sb colorimetric method [20].

Table 1. Soil physicochemical properties, plant diversity, and dominant plant species at different slope positions $(p \leq 0.05$; least significant difference test, LSD; $\mathrm{n}=3$ ).

\begin{tabular}{|c|c|c|c|c|}
\hline & Lower slope & Middle slope & Upper slope & $\mathrm{F}$ \\
\hline $\mathrm{AP}\left(\mathrm{mg} \cdot \mathrm{kg}^{-1}\right)^{\mathrm{a}}$ & $4.71 \pm 0.61 \mathrm{~b}$ & $5.89 \pm 0.27 \mathrm{ab}$ & $6.52 \pm 0.15 \mathrm{a}$ & $5.40^{*}$ \\
\hline $\mathrm{pH}$ & $7.46 \pm 0.19 \mathrm{a}$ & $7.74 \pm 0.07 \mathrm{a}$ & $7.89 \pm 0.04 \mathrm{a}$ & 3.16 \\
\hline $\mathrm{TN}\left(\mathrm{g} \cdot \mathrm{kg}^{-1}\right)^{\mathrm{a}}$ & $4.60 \pm 0.38 \mathrm{~b}$ & $5.78 \pm 0.27 \mathrm{a}$ & $6.30 \pm 0.03 \mathrm{a}$ & $10.48^{*}$ \\
\hline $\mathrm{SOC}\left(\mathrm{g}^{\mathrm{kg}}\right)^{-1}$ & $61.38 \pm 2.81 \mathrm{~b}$ & $66.49 \pm 0.93 \mathrm{ab}$ & $73.28 \pm 1.19 \mathrm{a}$ & $5.47^{*}$ \\
\hline $\mathrm{R}^{\mathrm{b}}$ & $40 \pm 6 \mathrm{a}$ & $40 \pm 4 \mathrm{a}$ & $44 \pm 5 \mathrm{a}$ & 0.2 \\
\hline $\mathrm{E}^{\mathrm{b}}$ & $0.96 \pm 0.003 \mathrm{a}$ & $0.92 \pm 0.03 \mathrm{a}$ & $0.98 \pm 0.01 \mathrm{a}$ & 2.76 \\
\hline $\mathrm{H}^{\prime \mathrm{b}}$ & $4.54 \pm 0.26 \mathrm{a}$ & $4.53 \pm 0.12 \mathrm{a}$ & $4.89 \pm 0.22 \mathrm{a}$ & 0.95 \\
\hline \multirow{2}{*}{ Dominant species } & Syzygium championii & Loropetalum chinense & Pittosporum tonkinense & - \\
\cline { 2 - 5 } & Loropetalum chinense & Pittosporum tonkinense & Syzygium championii & - \\
\cline { 2 - 5 } & Pyracantha fortuneana & Syzygium championii & Pyracantha fortuneana & - \\
\hline
\end{tabular}

Values are the means of three replicates with associated standard errors; means in a row followed by the same (non-superscript) lowercase letter are not significantly different at $p<0.05$ (LSD).

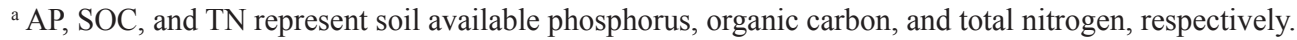

${ }^{\mathrm{b}} \mathrm{R}, \mathrm{E}, \mathrm{H}$ ' represent plant richness, evenness, and the Shannon-Wiener index, respectively. 


\section{Statistical Analyses}

Statistical analyses were performed in SPSS 19.0 for Windows (SPSS Inc., Chicago, IL). Differences at $p<0.05$ were considered statistically significant based on the least significant difference (LSD) test. Data that were not normally distributed were $\log _{(x+1)}$ transformed. Pearson correlation analysis was used to assess the relationship between microbial abundance and environmental factors. Redundancy analysis (RDA) was applied to visualize the effects of soil physicochemical characteristics and plant diversity on microbial community composition, and was conducted

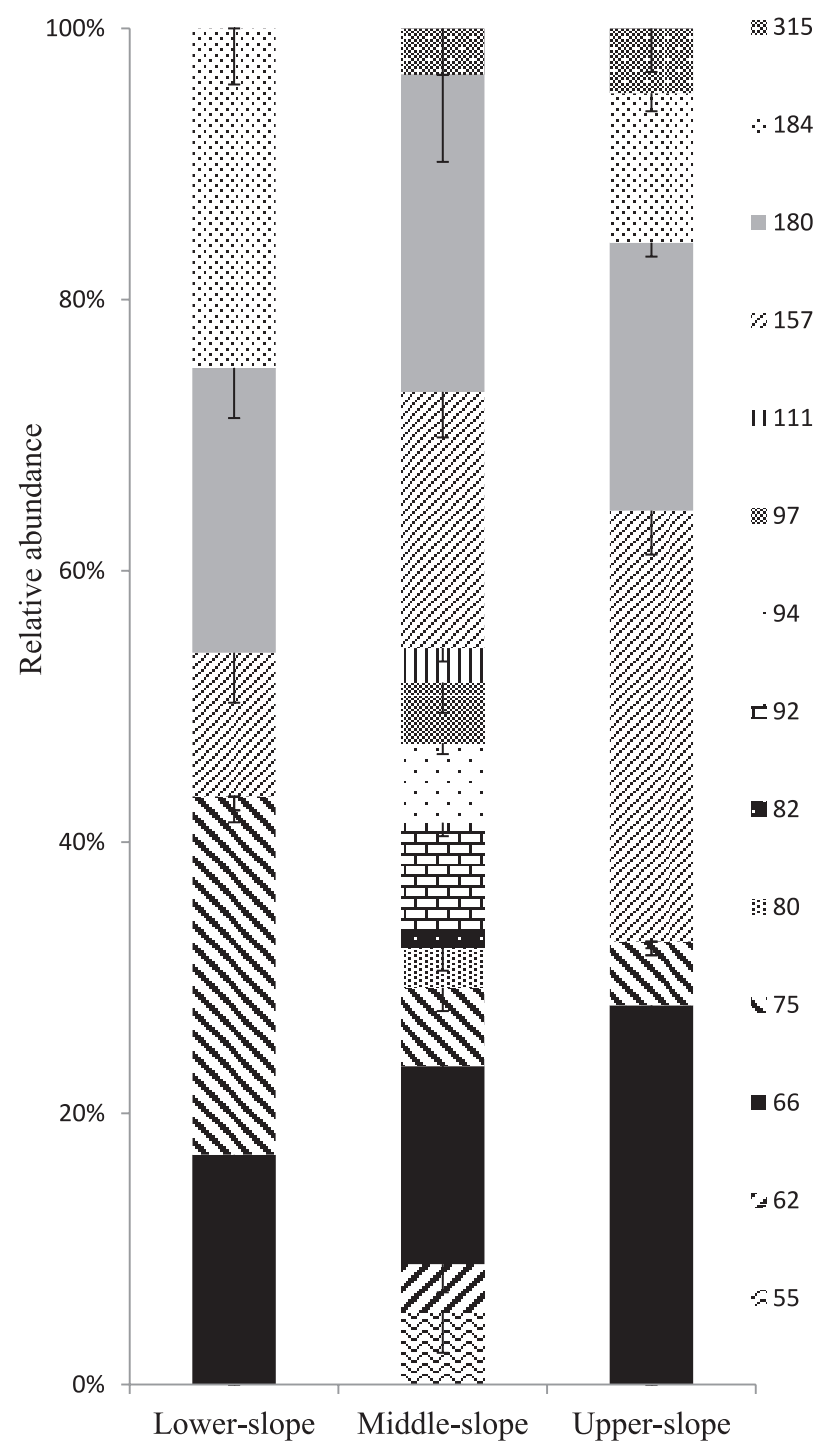

Fig 1. Average relative abundance of free-living nitrogenfixing bacteria among three slope positions, based on terminal restriction fragments (T-RFs), as determined by endonuclease digestion with HaeIII. The relative abundance of T-RFs is given as a percentage of the total peak area. Fragment sizes in the graph indicate the size of the experimental T-RFs. Bars indicate SE $(n=3)$. Twelve T-RFs $(55,62,75,80,82,92,94,97,111,157$, 184 , and $315 \mathrm{bp}$ ) from nitrogen-fixing bacteria significantly differed among the three slope positions. with CANOCO 5.0 (Microcomputer Power, Inc., Ithaca, NY). A preliminary detrended correspondence analysis (DCA) showed that the gradient length was always less than three standard deviations. Thus, linear responses were expected for data analysis.

\section{Results}

\section{Soil Properties and Plant Diversity}

Soil properties observed in the present study varied significantly along a slope gradient, except $\mathrm{pH}$ (Table 1). The contents of soil available phosphorus, soil organic carbon, and total nitrogen were higher in middle- and upper-slope soils than in lower-slope soils. Soil pH, ranging 7.46 from 7.89 , was not significantly different among the three slope positions. The probable reason maybe that soil $\mathrm{pH}$ is closely related to parent material. Soil $\mathrm{pH}$ along slopes was the same parent material, thus no significant difference was observed.

Table 1 shows the top three dominant species in each of the slope positions. Syzygium championii was common across the slope gradient. Pyracantha fortuneana was co-dominant species between lowerand upper-slope, while Pittosporum tonkinense was co-dominant species between middle- and upper-slope. Plant diversity indices (Shannon-Wiener diversity, richness, and evenness) were not significantly different among the three slope positions.

\section{Abundance and Composition of Free-Living Nitrogen-Fixing Bacterial Communities}

Fourteen T-RFs for free-living nitrogen-fixing bacteria were obtained (Fig. 1); of these, 5, 13, and 6 were found for the lower, middle, and upper slopes, respectively. Of the 14, 12 T-RFs differed among the three slope positions, and three of them $(66,157$, and $180 \mathrm{bp}$ ) predominating ( $48 \%$ of all obtained T-RFs). The

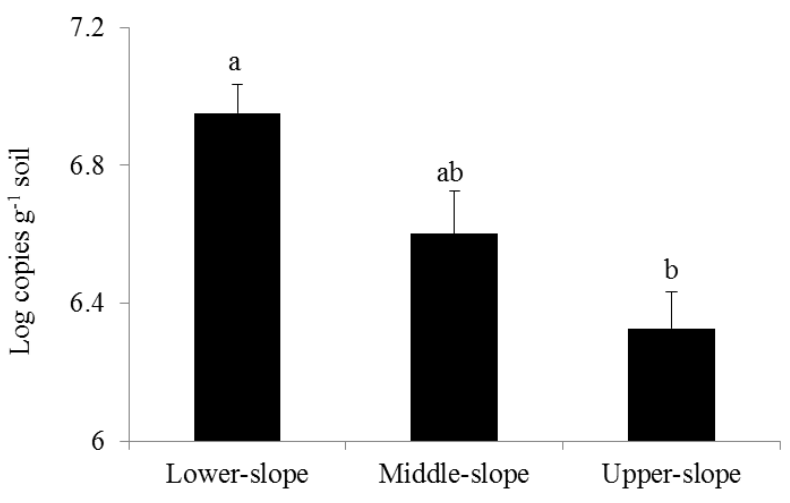

Fig 2. Copy numbers for free-living nitrogen-fixing bacteria among three slope positions. Different letters indicate significant differences between slope positions $(p<0.05$; LSD test). Bars indicate $\mathrm{SE}(n=3)$. 
rare T-RFs $(55,62,80,82,92,97$, and $111 \mathrm{bp})$ were only observed in the middle slope.

Bacterial abundance (number of copies) across the three slope positions ranged from 6.32 E6 to 6.95 E6 (Fig. 2) and was higher in lower-slope soils than in upper-slope soils.

\section{Relationships among Free-Living Nitrogen-Fixing Bacterial Communities, Plant Communities, and Soil Properties}

Soil available phosphorus $\left(p<0.05 ; \mathrm{R}^{2}=-0.707\right)$, organic carbon $\left(p<0.05 ; \mathrm{R}^{2}=-0.726\right)$, and total nitrogen contents $\left(p<0.05 ; \quad \mathrm{R}^{2}=-0.711\right)$ were all positively correlated with free-living nitrogen-fixing bacterial abundance (Pearson correlation).

a)

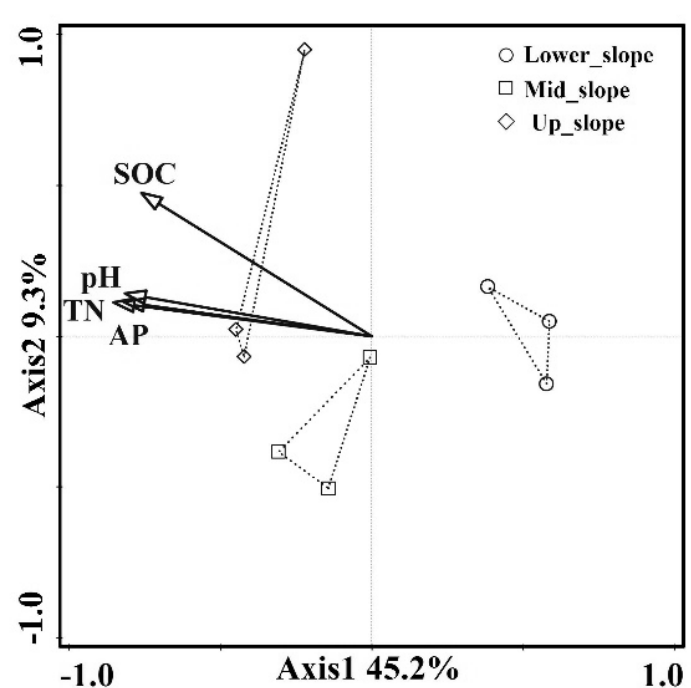

b)

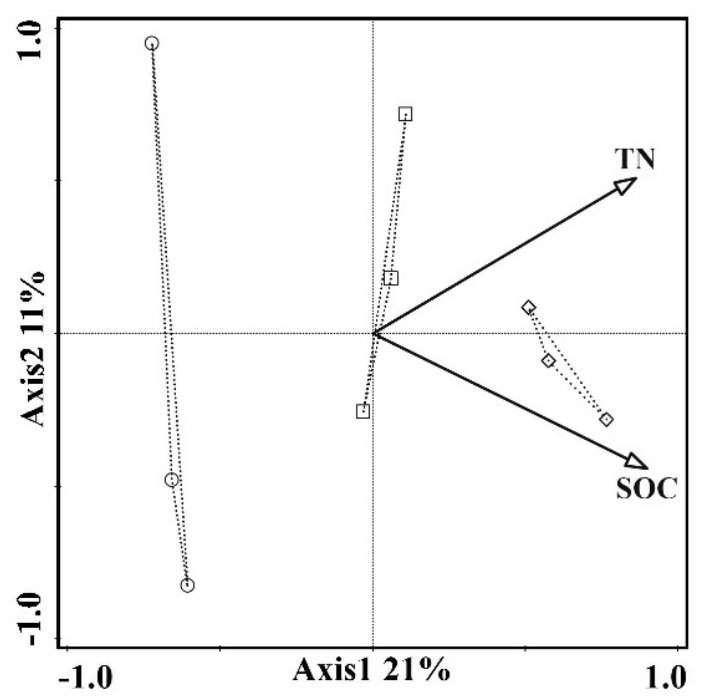

Fig 3. Relationships among free-living nitrogen-fixing bacterial communities, plant communities, and soil physicochemical properties based on redundancy data analysis. AP, SOC, and TN represent soil available phosphorus, organic carbon, and total nitrogen, respectively. a) Free-living nitrogen-fixing bacterial communities and b) plant communities.
Results of the RDA revealed that $\mathrm{pH}(p=0.02$, $\mathrm{F}=3.2)$, soil organic carbon $(p=0.026, \mathrm{~F}=2.9)$, available phosphorus $(p=0.01, \mathrm{~F}=3.2)$, and total nitrogen $(p=0.02, \mathrm{~F}=3.5)$ were significantly correlated with the free-living nitrogen-fixing bacterial community composition (Fig. 3a). These factors explained 45\% of the variance in bacterial community composition (Fig. 3a).

RDA further showed that soil organic carbon $(p=0.046, \mathrm{~F}=1.7)$ and total nitrogen $(p=0.047$, $\mathrm{F}=1.1)$ were significantly correlated with plant community composition (Fig. 3b), explaining $31 \%$ of the variance (Fig. 3b).

\section{Discussion}

In this study, free-living nitrogen-fixing bacterial communities exhibited a strong spatial structure depending on slope elevation, likely due to the large number of niches created by higher spatial heterogeneity in soil nutrients (Fig. 3a). Additionally, compared with results from other ecosystems [21], nifH gene abundance (Fig. 2) was slightly higher in our study site, lending credence to the suggestion that free-living bacteria contribute more to nitrogen input in karst ecosystems.

Bacterial abundance differed between various heights on the slope (Fig. 2). A slope gradient may cause correlated variation in soil nutrients [22], thus creating different microhabitats and indirectly influencing microbial abundance. High nutrient levels, especially of carbon, tend to create optimal conditions for nitrogen fixation by free-living bacteria [23], because the reduction of atmospheric dinitrogen to ammonia is a very energy-consuming process. However, in contrast to the previous reports $[13,24]$, we found that bacterial abundance increased with decreasing soil nutrient content along a slope gradient. One possible reason for this outcome is that the nutrient contents in our study soils were above the minimum threshold for reduced bacterial abundance. As a result, soil nutrients may not have greatly influenced the number of bacteria; instead, other factors, such as molybdenum impacting free-living $\mathrm{N}_{2}$ fixation [25], may have been the predominant factor.

Although the community composition of free-living nitrogen-fixing bacteria was quite variable at our study site (Fig. 3a), three predominant T-RFs $(66,157$, and 180 bp) accounted for $48 \%$ of total bacterial T-RFs across three slope positions. As the remaining 52\% consisted of rare free-living bacteria, our results suggest that in heterogeneous karst soils, these less common groups may be as important as the dominant groups in nitrogen fixation.

The variation in bacterial community composition was mainly due to changes in soil properties, rather than changes in plant communities [26]. In this study, some microbial taxa were more susceptible to soil $\mathrm{pH}$, and variation within a narrow range shifted bacterial community composition (Table 1; Fig. 3a). Our results 
accord with previous research demonstrating that among various soil properties, $\mathrm{pH}$ is the main driver of free-living bacterial community composition [28]. Soil $\mathrm{pH}$ affects the microbial community mainly through influencing soil nutrient availability [28] and can result in the dominance of one taxon. For example, the symbiotic Bradyrhizobium is prevalent in neutral and high-pH soils [29, 30], a pattern that has also been reported by Liu et al. (2015) [9] in karst shrub ecosystem sharing the same study area with our present study. Taken together, these findings indicate that the distribution patterns of free-living nitrogen fixers in karst regions reflects the adaptability of particular taxa to microhabitats generated from differing soil properties.

We found that measured values of soil physicochemical properties were higher in upper-slope soils than in lower-slope soils (Table 1), contradicting results from other regions [31]. The between-study differences may be related to specific geographical characteristics in karst regions. Specifically, slope position can indirectly affect soil properties by influencing hydrothermal conditions. In the upper slopes of the karst region, for example, underground soil erosion is more intense compared with surficial soil erosion, whereas lower slopes exhibit the opposite pattern [32]. Thus, lower slopes exhibit greater soil erosion and reduced soil nutrients (Table 1). Alternatively, compared with lower slopes, upper slopes in a karst ecosystem have more exposed bedrock and chemical limestone dissolution, which allows for the easy formation of micromorphologies such as stone pits, stone-drains, and stone cisterns. These micromorphologies benefit the retention of soil sediments, allowing upper-slope soils to possess more nutrients than lower-slope soils.

Plant community composition also varied along a slope gradient (Fig. 3b), supporting results from previous studies [33, 34]. Similar to our arguments regarding bacterial community composition, differences in soil nutrients across slope positions were likely the main influence on variation in plant community composition [35]. Our results demonstrated that plant community composition was correlated with soil nutrients like total nitrogen and soil available phosphorus (Fig. 3b), in support of findings from other karst region studies [36]. However, slope position did not strongly affect plant species diversity (Table 1), at odds with the previous research examining a heterogeneous deciduous broadleaved forest [37]. One likely reason for our results is that the slope gradient was not extreme; the greatest vertical height difference between the upper and lower slopes was only $325 \mathrm{~m}$ at our study site. This relatively minor change in elevation may have been insufficient to cause any topography-based differentiation in plant diversity. Supporting this idea is the finding that topographical factors have a stronger effect on plant distribution in karst regions when the slopes are steep, rather than gentle [38].

\section{Conclusions}

In conclusion, the distribution patterns of free-living nitrogen-fixing bacteria were identified along a slope gradient in a karst region. These bacterial communities exhibited strong spatial structure depending on slope height. The change of this bacterial community along slopes was likely associated with fluctuations in soil properties (e.g., amount of organic carbon and nitrogen). Therefore, these results highlighted the importance of soil heterogeneity in maintaining bacterial diversity. Future investigations could expand on our current work by examining how bacterial communities vary vertically in the soil, rather than horizontally, as was the focus here. Nonetheless, our results have provided greater insight on the spatial structure of free-living nitrogen-fixing bacterial communities and contributed to our overall understanding of the underlying processes behind bacterial community dynamics.

\section{Acknowledgements}

This project was supported by grants from the National key Research Program (2017YFC0505503), the National Natural Science Foundation of China (31741021), the Natural Science Foundation of Guangxi (2016GXNSFBA380179, 2017GXNSFAA198241), and the Western Light Program from CAS (Y62306040).

\section{Conflict of Interest}

The authors declare no conflict of interest.

\section{References}

1. LIU J.J., SUI Y.Y., YU Z.H., SHI Y., CHU H.Y., JIN J., LIU X.B. High throughput sequencing analysis of biogeographical distribution of bacterial communities in the black soils of northeast China. Soil Biol. Biochem. 70, 113, 2014.

2. BAHRAM M., PEAY K.G., TEDERSOO L. Localscale biogeography and spatiotemporal variability in communities of mycorrhizal fungi. New Phytol. 205 (4), 1454, 2015.

3. LIU J.J., SUI Y.Y., YU Z.H., SHI Y., CHU H.Y., JIN J., LIU X.B., WANG G.H. Soil carbon content drives the biogeographical distribution of fungal communities in the black soil zone of northeast China. Soil Biol. Biochem. 83, 29, 2015.

4. SHEN C.C., XIONG J.B., ZHANG H.Y., FENG Y.Z., LIN X.G., LI X.Y., LIANG W.J., CHU H.Y. Soil pH drives the spatial distribution of bacterial communities along elevation on Changbai Mountain. Soil Biol. Biochem. 57, 204, 2013.

5. BONNETT P.E., MOORE C.E., BURBACH M. Vegetable oils as nitrogen fixing bacteria preservative. Google Patents, 2012. 
6. PEOPLES M.B., HERRIDGE D.F., LADHA J.K. Biological nitrogen fixation: an efficient source of nitrogen for sustainable agricultural production? Plant Soil, 174, 3, 1995.

7. LI D.J., WANG Z.C., SUN X.B., ZHANG Q.S., WANG K.L. Tree species effects on asymbiotic $\mathrm{N}_{2}$ fixation in subtropical karst and non karst forests. Soil Biol. Biochem.117,185, 2018.

8. REED S.C., CLEVELAND C.C., TOWNSEND A.R. Functional ecology of free-living nitrogen fixation: a contemporary perspective. Annu. Rev. Ecol. Evol. S. 42, 489, 2011.

9. LIU L., HE X.Y., WANG K.L., XIE Y.J., XIE Q., O'DONNELL A.G., CHEN C.Y. The Bradyrhizobiumlegume symbiosis is dominant in the shrubby ecosystem of the Karst region, Southwest China. Eur. J. Soil Biol. 68, $1,2015$.

10. ZHANG W., ZHAO J., PAN F.J., LI D.J., CHEN H.S., WANG K.L. Changes in nitrogen and phosphorus limitation during secondary succession in a karst region in southwest China. Plant Soil, 39 (1-2), 77, 2015.

11. ZHANG W., CHEN H.S., WANG K.L., HOU Y., ZHANG J.G. Spatial variability of soil organic carbon and available phosphorus in a typical Karst depression, northwest of Guangxi. Acta Ecology Ica Sinica, 27 (12), 5168, 2007.

12. LIANG Y.M., SU Y.R., HE X.Y., CHEN X.B., HU Y.J. Various effects on the abundance and composition of arbuscular mycorrhizal fungal communities in soils in karst shrub ecosystems. Environmental Science, 38 (11), 4828, 2017 [In Chinese].

13. MIRZA B.S., POTISAP C., NüSSLEIN K., BOHANNAN B.J.M., RODRIGUES J.L.M. Response of free-living nitrogen-fixing microorganisms to land use change in the Amazon rainforest. Appl. Environ. Microbiol. 80 (1), 281, 2014.

14. PRESCOTT C.E., GRAYSTON S.J. Tree species influence on microbial communities in litter and soil: current knowledge and research needs. Forest Ecol. Mana. 309, 19, 2013.

15. LIANG Y.M., PAN F.J., HE X.Y., CHEN X.B., SU Y.R. Effect of vegetation types on soil arbuscular mycorrhizal fungi and nitrogen-fixing bacterial communities in a karst region. Environ. Sci. Pollut. R. 23 (18), 18482, 2016.

16. CHEN X.B., SU Y.R., HE X.Y., WEI Y.W., WEI W.X., WU J.S. Soil bacterial community composition and diversity respondto cultivation in Karst ecosystems. World J. Microb. Biot. 28 (1), 205, 2012.

17. CHEN Z., LIU J.B., WU M.N., XIE X.L., WU J.S., WEI W.X. Differentiated response of denitrifying communities to fertilization regime in paddy soil. Microb. Ecol. 63,446, 2012.

18. YUAN H.Z., GE T.D., CHEN C.Y., O'DONNELL A.G., WU, J.S. Significant role for microbial autotrophy in the sequestration of soil carbon. Appl. Environ. Microbiol. 78 (7), 23, 2012.

19. BREMER J.M. Total nitrogen. In: Black CA (ed) Methods of soil analysis. American Society of Agricultural, USA, 2, 1149, 1965.

20. COLWELL J.D. The estimation of phosphorus fertilizer requirements of wheat in southern New South Wales by soil analysis. Aust. J. Exp. Agric. Anim. Husb. 3, 190, 1963.

21. REARDON C.L., GOLLANY H.T., WUEST S.B. Diazotroph community structure and abundance i $\mathrm{n}$ wheat-fallow and wheat-pea crop rotations. Soil Biol. Biochem. 69, 406, 2014.
22. GOTSCH S. Land cover and slope position affect water use and microclimate in the tropical montane cloud forests of Central Veracruz, Mexico. New Frontiers in Tropical Biology: The Next 50 Years (A Joint Meeting of ATBC and OTS). Atbc, 2013.

23. DELUCA T.H., DRINKWATER L.E., WIEFLING B.A., DENICOLA D.M. Free-living nitrogen-fixing bacteria in temperate cropping systems: influence of nitrogen source. Biol. Fertil. Soils 23,140, 1996.

24. SENE G., SAMBA-MBAYE R., THIAO, M., KHASA D., KANE A, Manga A., MBAYE M.S., SYLLA S.N. The abundance and diversity of legume-nodulating rhizobia and arbuscular mycorrhizal fungal communities in soil samples from deforested and man-made forest systems in a semiarid Sahel region in Senegal. Eur. J. Soil Biol. 52, 30, 2012.

25. ROUSK K., DEGBOE J., MICHELSEN A., BRADLEY R., BELLENGER J.P. Molybdenum and phosphorus limitation of moss-associated nitrogen fixation in boreal ecosystems. New Phytol. 214, 97, 2017.

26. ZHANG Y., CAO C.Y., PENG M., XU X.J., ZHANG P., YU Q.J., SUN T. Diversity of nitrogen-fixing, ammoniaoxidizing, and denitrifying bacteria in biological soil crusts of a revegetation area in Horqin Sandy Land, Northeast China. Ecol. Eng. 71, 71, 2014.

27. XU C.W., YANG M.Z., CHEN Y.J., CHEN L.M., ZHANG D.Z., MEI L., SHI Y.T., ZHANG H.B. Changes in nonsymbiotic nitrogen-fixing bacteria inhabiting rhizosphere soils of an invasive plant Ageratina adenophora. Appl. Soil Ecol. 54, 32, 2012.

28. ZHALNINAA K., DIAS R., DöRR DE QUADROS P., DAVIS-RICHRADSON A., Camargo F.A.O., Clark I.M., MCGRATH S.P., HIRSCH P.R., TRIPLETT E.W. Soil pH determines microbial diversity and composition in the park grass experiment. Microb. Ecol. 69 (2), 395, 2015.

29. CHEN W.X., WANG E.T. Rhizobia in China, Science Press, Beijing, 2011.

30. LI Q.Q., WANG E.T., ZHANG Y.Z., ZHANG Y.M., TIAN C.F., SUI X.H., CHEN W.F., CHENW.X. Diversity and Biogeography of Rhizobia Isolated from Root Nodules of Glycine max Grown in Hebei Province, China. Microb. Ecol. 61 (4), 917, 2011.

31. ZHANG D., ZHANG Y.X., QU L.Y., MA K.M., DAI S.D. Effects of slope position on soil microbial biomass of Quercus liaotungensis forest in Dongling Mountain. Acta Ecologica Sinica, 32 (20), 6412, 2012 [In Chinese).

32. ZHANG X.B., BAI X.Y., HE X.B. Soil creeping in the weathering crust of carbonate rocks and underground soil losses in the karst mountain areas of southwest china. Carbonate Evaporite, 26 (2), 149, 2011.

33. BAI X. H., ZHANG J.T., CAO K., WANG Y.Q., SEHRISH S., CAO G. Relationship between forest communities and the environment in the Xiaowutai Mountain National Nature reserve, Hebei. Acta Ecologica Sinica, 37 (11), 3683, 2017 [In Chinese].

34. TAKAHASHI K., MURAYAMA Y. Effects of topographic and edaphic conditions on alpine plant species distribution along a slope gradient on Mount Norikura, central Japan. Ecol. Res. 29 (5), 823, 2014.

35. DU H., PENG W.X., SONG T.Q., ZENG F.P., WANG K.L., SONG M., ZHANG H. Spatial pattern of woody plants and their environment interpretation in karst forest of southwest China. Plant Biosyst. 149, 1, 2013.

36. PENG W.X., SONG T.Q., ZENG F.P., WANG K.L., DU H., LU S.Y. Relationships between woody plants and environmental factors in karst mixed evergreen-deciduous 
broadleaf forest, southwest China. J. Sci. Food Agr. 10 (1), 890, 2012.

37. FU B.J., LIU S.L., MA K.M., ZHU Y.G. Relationships between soil characteristics, topography and plant diversity in a heterogeneous deciduous broad-leaved forest near Beijing, China. Plant Soil, 261 (1-2), 47, 2004.
38. ZHANG Z.H., HU G., NI J. Effects of topographical and edaphic factors on the distribution of plant communities in two subtropical karst forests, southwestern China. J. Mt. Sci. 10 (2), 95, 2013. 